\title{
Analysis of the power of the old fisherman Santiago in the old man and the sea
}

\author{
Hong Yang, Zhenzhen Zhang \\ College of Foreign Languages, Hebei University of Technology, Tianjin, 300401, China
}

Keywords: the old man and the sea; old fisherman; Santiago; power

\begin{abstract}
The old man and the sea" is a famous American Hemingway's representative work.The protagonist old fisherman Santiago is strongly shaped as the "tough guy" bythe writer. He believes that "people" can only be eliminated and can't be defeated.In the fight with the bad luck, Santiago showed great persistent courage and inexhaustible perseverance and the remarkablepower, and his invariable toughness. This paper analyzed the personality traits of the old fisherman Santiago, and emphatically elaborated onthe power of the old fisherman Santiago in his firm faith and hisnature charm.
\end{abstract}

\section{Introduction}

20 th-century'sfamous American writer Hemingway described a tough guy who dares to face deformity and pain of life byhis own limit individual life force. With his own perseverance, dignity, and strong will, he dares toconfront the fate of failure and death.Santiago is the typical symbol of Hemingway's tough guy image. He believes that "people" can only be eliminated and can't be defeated.In this novel, the old fisherman Santiago failed to catch the fish for eighty-four days. And in the eighty-fifth day, he chose to drive the boat out to the sea alone, and catch a big marlin. After three days and two nights' dogfight, he finally caught the big fish. Unfortunately, in return, the shark attacked and only leftthe wreckage ofthe big fish. Readers are always appreciate the unyielding fighting spirit of Santiago in the face of the repeated failures, because it reflects a kind of elegant temperament - grace under pressure. It is Santiago who links the tough guy image with a kind of human connotation. His strong spiritual powerstrengthens and enriches the connotation of the artistic image, and leaves great impact on the hearts of readers.

\section{The personality traits of the old fisherman Santiago}

One is enough perseverance to move on. Old fisherman Santiago is the hero of the novel "the old man and the sea". Years' struggle and suffering from the harsh life worn out the old fisherman and made him thin and haggard, but his eyes are still as blue as sea water and filled with cheerfulness and unyielding spirit. In the beginning of the novel, the old fisherman Santiago was downwith bad luck.He has been failed to catch the fish for eighty-four days. Even thoughthe child, who was always with him, left him at the time of the 40th day, that does not let him lose confidence, he still made up his mind to go further into the sea, for this is the task he was born to do.As a fisherman, all his dignity and honor depended on whether he could finish the task. So,in the moonlight, the old fisherman Santiago determined to drive the boat out and set uphis sailing in the ocean, to patiently carry on his task to search and arrest fish.

The second is always carrying on. On the eighty-fourthafternoon,Old fisherman Santiago finally found his long-awaited fish. However, the fish was so strong that it pulled the ship and the old fisherman towards the calm sea.The whole day was gone, and the fish didn't settle, but the old man was not discouraged. Because he strongly held the belief that no matter how big the fish was, it couldn't drag the ship on forever, and he has decided to die with the fish. Old fisherman Santiago believes that he could keep on, no matter how much longer the fish could hang on. Before long, the fish dragged the silk yank so strongly that hurt his hand, and soon situation got worse, his hand began to cramp.It never rains but it pours. Fatigue, pain, hunger, thirst came in and mercilessly tormented him, but he's still in persistence and patience. Until the next day afternoon, themysterious fish finally showed up for the second time, which highly excited the old fisherman. Unfortunately, 
the fish disappeared into the sea again and made its next appearance three days later. But the old man overcame all the torments,summed up all his rest power and finally killed the fish.Even though the old fisherman was the winner, he was exhausted.

The third is to dare to fight back. The old fisherman Santiago returned home in triumph. On the return, he came cross the unusually ferocious shark again. The fruits of his hard work soon fell victims to the hateful sharks. Theybite at least forty pounds away. Among them, the worse is that his fishing fork, together with the rope were taken away by the sharks. You could do all you can to destroy him, but you couldn't defeat him.He is such a person, who would never bow to fate and give in.He tied the knife on the oar topierced the sharks. After the knife broke, he was with the propeller and the rudder, with short stick, with all the items can be used to knock and fight against the sharks fiercely. He is determined to fight with them.He is this kind of person, who is indomitable and full of power. However,in the middle of the night, herds of the shark swam towards the old man andhis boat. Old fisherman Santiagoagaincame to fight fiercely with them.The result is that a dead fish were eaten by the sharks. A bit weird, the old fisherman Santiago feels more relaxed at this time. Thought of nothing, he drove the boat deftly to the port.The next morning, the old man Santiago fell sleep again in the hut by the side of the rode..

The above feature is the most successful, the most brilliant, and the most perfect indomitable tough guy image created by the writer Hemingway. Old fisherman Santiago, who was always fighting with the harsh life and bad luck,failed again and again in the battle. He never yield to failure. Instead, He is very brave to face failure. In some sense, he is the winner, especially in his manner towards failure. Old fisherman Santiago never loses his dignity, and, in spirit, he will always be a winner.

\section{The interpretation of the power of old fisherman Santiago}

\subsection{The symbolic meaning of Santiago's power}

In the novel "the old man and the sea" the hero old fisherman Santiago is the typical symbol of tough guy. He can boldly fight with all kinds of hardships of life, challenges to the limit of life, and bravely go beyond it, so as to earn his honor and dignity.From the height of an unprecedented shock ravishing, he showed people the value of life. In the process of fighting with the big fish and the sharks, the old fisherman Santiago successfully showed us thegood symbolism of thestrong hero image by his confidence and courage, just like a prelude for deep and DiHui cello concerto. The fishermen made a living by fishing in the boundless sea.It is a blood mildew that a lonely old fisherman Santiago rowed the boat, has failed to catch a fish for eighty-four days. However, the old fisherman Santiago didn't lose confidence.As the saying goes:” eyes are the window to the soul."This blue eyescarried a symbol of bad luck, so as to reveal the truth that the old fisherman Santiago is definitely not the fate of fortitude character. He is optimistic, open and bright, and never give up the brave spirit. Old fisherman Santiago decided, on the eighty-fifth day, to drivethe ship out to the sea to catch the big fish.this is the old fisherman's single-minded pursuit of ideal, which is also the important performance of human efforts to conquer their own cowardice. In the trial of fighting with the big marlin, knowing that its strength is stronger than his, but he still carried on and showed his surprising strength.

The language of the novel "the old man and the sea" is powerful. In battle with the big marlin, it not only cares about the physical confrontation, more important is a confirmation of the self-spirit.The spirit is a specific performance that a tough guy who defendedhis dignity, so as to realize his own life value. With the continuous development of the plot, Hemingway once again pushed the old man into the hot water toface the hateful sharks, which people are hard to resist. However, the old fisherman Santiago armed him with a spear, sword and OARS and the tiller and all personal means such as wooden sticks to fight with the sharks. As Author Ernest Hemingway put it, when the old fisherman was hungry he would tear off a piece of raw fish to eat.The old fisherman Santiago was constantly under the great challenge of his unfortunate fate, which brought his brave and tough style out, and helpedhim overwhelm the difficulties again and again. The readers made sense of his never giving in to difficulties and unyielding spirits, which is the important guarantee 
of a better future

\subsection{Old fisherman Santiago's power represents a strong faith}

Old fisherman Santiago is a respectable hero, who is not only able to overcome death but also a brave man. He battled with the nature and ferocious sharks again and again desperately. This is the process that the hero survived from deathagain and again. He fought with the sea, it is not just the general struggle to conquer nature, it is the battle with the life. The old fisherman Santiago showed us the philosophy of life by his own experience. He is striving for the implementation of self-worth.But, just as a literary critic Buehler said, when death comes, theprotagonists of Hemingway's novels will never commit suicide, on the contrary, they will understand how to face it.So it goes with what Santiago said, people can be destroyed, but not defeated. In his fight with the sharks, he comprehend the philosophy of life. The fight is a very effective mechanism of self-reflection and spur, and it strengthened his belief in self-flagellation, and sublimatedhis own personality.

The tone of the novel" the old man and the sea" is so clam and objective that it reveals the old fisherman Santiago's endless grace under pressure. As a lonely old man, and also an old man make a living by fishing. In order to survive, he must go to sea to go fishing. Although fishing alone in the sea meansputting himself under great danger, especiallyconfronting the threat of death.However, no matter under the helplessenvironment, or in fierce fighting of survival, the old fisherman Santiago did not show a spark of emptiness and confusion. This stems from the countless times' survival from the desperate situationby his firm faith and confidence. From the beginning to the end, old fisherman Santiago confronted the possible failure with a very calm attitude. Therefore, heuse very common mentality to challenge the possible arrival of death. Now that it has come, let the storm come more violently. In such a cruel and harsh environment under such a fierce battle, the old fisherman Santiago fully demonstrateshis firm belief,and his elegant temperament -grace under pressure, showshis strong personality power.

\subsection{The charm of Santiago's power}

Old fisherman Santiago is themale leading role of the novel "the old man and the sea", the tough guy is Hemingway's own life experiences and it is the outstanding performance of the unruly personality of him in art. Santiago always carry the shadow of Hemingway, who is full of the charm of human nature. As a typical representative of the lost generation, Hemingway's life has the legendary experience, participated in world war one and two, and the war in Spain. He loved bullfighting, hunting and all kinds of adventures.Though scarred on the body, as a man, henever gives in to life, andactively explores the value of life and the track. The suffering of these life experiences for Hemingway undoubtedly helped him make the creation of old fisherman Santiago, who has a resolute heart and full of power, and it provides a good material life prototypefor his creation.Therefore, in a sense, the old fisherman Santiago is the embodiment of Hemingway himself. It is worth mentioning, Hemingway chose such a man, whosehealth goes from bad to worse, as the representative of the tough guy, instead of choosing a strong physique and energetic young fishermen to be the hero. This wise choice can actually enhance Santiago's charm, which coincidently showsthe writer's ability on the characterization of ingenuity and originality.

\section{Conclusion}

In a word, Hemingway described the old lonely fisherman,confronted the difficulties under the great pressure, which is desolate but full of tragic beauty. At the same time, this novel successfully created a real tough guy, making the audience admire Santiago's brave character very much. The protagonist personality of old fisherman Santiago is quite successful, pushing people to a new level. It is really unique, and inspires today's young people, and itcreates a very far-reaching practical significance to the young people.

\section{References}

[1]Yang Zhi. The Classic Tough Guy Image in “The Old Man and the Sea”[J]. Journals of Guiyang 
College(Social Science),2006(1).

[2]Dai Sha. The Unbeatable Tough Guy and the Embodiment of Strong and Brave---Appreciation of "The Old Man and the Sea” by Hemingway[J]. Journals of Hetian Normal Higher Technology College, 2010(2)

[3]Li Zhanquan. Analysis of Tough Spirit--- Appreciation of "The Old Man and the Sea” by Hemingway[J]. New Western(theory), 2012(3)

[4]Ling Wei. The Recession, Repair and Refresh of Power - Analysis about The Old Man in San Diego in "The Old Man and the Sea"[J]. Journals of Jinhua Vocational Technical College,2013(2).

[5]Fan Xing. Seen the Tough Guy Image from “The Old Man and the Sea”[J]. Journals of Lanzhou Educational College,2013(6) 